\title{
INFORMAL INDUSTRIES IN INDIA: PRESENT SCENARIO, GAP AND OPPORTUNITIES
}

\author{
BY \\ Krishna Kumar Thakur, \\ Research Scholar, Department of Business Administration, Assam Don Bosco University, Guwahati, \\ Assam \\ Email: krishhh83@gmail.com \\ Sankar Jyoti Nath, \\ Research Scholar, Department of Business Administration, Assam Don Bosco University, Guwahati, \\ Assam \\ Dr. Biju Mani Das \\ School of Commerce and Management, Assam Don Bosco University, Guwahati, Assam \\ Email:biju.das@dbuniversity.ac.in
}

\begin{abstract}
:
India is one of the biggest markets in the world; here mainly two types of industry are in scenario either formal or informal. Whereas informal sector is widespread across the geography and it contributes to the economy of country. Most of the employment comes from this sector; still it is the most neglected sector in India. It is also the most exploited industry in India.
\end{abstract}

This study aims at gaining an in depth overview of the informal sector in Indian context.

Key points: Informal sector, Formal sector, Industries, Initiatives, India

\section{Introduction:}

There are several type of industries are available across the globe and for them, India is one of the biggest markets. As per the report published by International monetary fund and Central Statistics Organization in 2017, India has been reported as one of the emerging and major economy in the world and it is growing at a tremendous pace. It is also speculated that, India would be among one of the top three major economies in the world by next 10-15 years. $7.1 \%$ was the GDP of India in 201617 and it is also speculated that India will achieve a growth rate of $7.8 \%$ by end of 2019 (www.businesstoday.in, 2018). Indian market is mostly dominated by the unorganized players; the arrival of organized sectors from domestic and international front is ready to change the things.
All the market consists of organized or unorganized sector and there is a tremendous growth in the Organized, exceeding all previous estimates. Workers from unorganized are highest in number still they are the most neglected and vulnerable. The worker in unorganized sector consists of poor class people and they do not posses any assets still unorganized sector is considered to be very important segment contributing to the development of Indian economy.

Objective of the study:

1. To gain an overview of informal sector in India

2. Present scenario of informal sector in India

3. Governments initiatives for the upliftment of informal sector in India

4. Reason for growth in Informal sectors in India

5. Future aspects of informal sector in India

\section{Research Methodology:}

For the purpose of this study, all data from secondary sources have been collected.

\section{Informal Sector:}

Any industry which is not formally registered with any of the government agency or any industry which is neither being taxed by the government 
nor being monitored is termed as Informal industry. The informal industry in India has been labelled as industry under grey area or in other words it will be justified to say black market. There is a very significant contribution of informal industry towards the Indian economy. The informal industry in India is expanding at a very high speed and this informal industry is also marked as green zone for unskilled labour through which they earn their livelihood. The informal sector is commonly recognised as a sector consisting of unskilled or low skilled workers. India is witnessing a huge challenge in integrating the informal industry with formal industry. Inspite of several steps and initiatives taken by govt, it's very satisfactory result it could not be achieved. The difference between formal and informal sector is very vast and to bring similarity between formal and informal sector, there is long way to be covered. The terminology used for this industry informal or unorganized is used as synonyms or interchangeably. This industry is basically related with income generation for the people having low set of skill or totally unskilled. The primary objective of the people engaged with informal industry is to earn their daily expenses by getting a job in these industries. Informal industry in India runs at a very low level of organization in which it becomes very difficult to distinguish between labour and capital as factors of production. Informal industry in India operates at a very small level. The employment here is casual by nature, mutual understanding or personal and social relations rather than contractual arrangements with formal guarantees.

\section{Difference:}

\begin{tabular}{|l|l|l|}
\hline Differences & $\begin{array}{l}\text { Informal } \\
\text { Industry }\end{array}$ & $\begin{array}{l}\text { Formal } \\
\text { Industry }\end{array}$ \\
\hline
\end{tabular}

The major characteristics of the unorganized sector:

a. The presence of informal sectors is prevalent across India.

b. The supply always remains higher than the required manpower, the nature of work is temporary or casual also the people in this

\begin{tabular}{|l|l|l|}
\hline 1. & $\begin{array}{l}\text { Activities are } \\
\text { not tracked by } \\
\text { govt agencies }\end{array}$ & $\begin{array}{l}\text { All activities are } \\
\text { tracked by govt } \\
\text { agencies }\end{array}$ \\
\hline 2. & $\begin{array}{l}\text { Tax evasion is } \\
\text { rampant in } \\
\text { informal } \\
\text { industry }\end{array}$ & $\begin{array}{l}\text { Tax evasion is } \\
\text { difficult }\end{array}$ \\
\hline 3. & $\begin{array}{l}\text { There is } \\
\text { possibility of } \\
\text { income } \\
\text { generated being } \\
\text { slipped out } \\
\text { from inclusion } \\
\text { in GDP }\end{array}$ & $\begin{array}{l}\text { No } \\
\text { possibility }\end{array}$ \\
\hline 4. & $\begin{array}{l}\text { Employment } \\
\text { terms } \\
\text { conditions and } \\
\text { not clear or } \\
\text { fixed }\end{array}$ & $\begin{array}{l}\text { Employment } \\
\text { terms and } \\
\text { conditions are } \\
\text { clear and fixed }\end{array}$ \\
\hline 5. & $\begin{array}{l}\text { There is no } \\
\text { guarantee of } \\
\text { minimum } \\
\text { wages } \\
\text { employment or }\end{array}$ & $\begin{array}{l}\text { Employees are } \\
\text { protected under } \\
\text { various schemes } \\
\text { like minimum } \\
\text { wages act, } \\
\text { factories act etc }\end{array}$ \\
\hline 5
\end{tabular}

Similarity between Informal and Formal organizations:

An industry which has been categorised as Formal Industry may comprise of people from either formal or informal sector and the manpower structure for informal industry remains as it is in the formal sector. To elaborate the manpower scenario let us consider the case of a person who works as a freelancer. In case of freelancer, it is a part of both formal and informal industry where as if the case of a rickshaw puller being consider- it comes directly under unorganized and informal sector.

sector don't have any permanent source of income.

c. There is a total absenteeism of (in Informal Industry)-

- Hygienic or even work place

- Fixed rules \& regulations 
- Formal relation between employee and employer

- Trade Union

- Appropriate labour law

d. The informal industry has broadly been categories into two parts-

- Rural Informal Industry: Caste and community of an individual still remains the sole criteria for getting a job in rural area in an informal industry.

- Urban Informal Industry: In urban areas, the division of work based on caste and community is almost nil, but depends on other factors such as bulk migrant workers from rural area.

e. Debt laden and the burden to meet the daily needs are the main characteristics of workers associated with unorganized sector.

f. Exploitation can be said to exist at highest level in unorganized sectors in terms of wages, irregular working hours, and working environment.

g. Health hazards are there as the machine with which they used to work are mostly outdated or they don't have desired set of skills.

\section{Present Scenario of Informal Sectors:}

a. It would be very appropriate to mention that only 10 percent out of 470 million workforces is employed in organised sector (The Hans India, 2017).

b. Industries such as manufacturing, construction apart from agricultural sector are the major contributors towards the informal industry. According to National Sample Survey office (NSSO), the majority of job creations in Indian economy are from informal industry.

c. There is a huge contribution of Informal industry towards Indian Economy, though its ill effect cannot be ignored at large (National Statistics Commission, GoI, 2012).

d. The productivity is and value addition is very low as compared to any formal industry.

e. There is a huge revenue loss for the government from Informal industries as these industries are out of radar of monitoring authority.

\section{Governments Initiatives:}

In order to enhance the productivity of informal industry, creation of sustainable employment opportunities especially in the rural areas, the government of India has enacted The National Commission for Enterprises in the Unorganized Sector (NCEUS). This institution also aims at-

a. Enhancing the competitiveness of the sector,

b. To bring the informal sector within the institutional framework in several areas such as credit facility, providing raw material, provision for infrastructure, and technology up gradation and necessary marketing of the products.

c. To upgrade the required skill set and overall development of informal sector.

In relation to employment, India's socio-economic system is more of informal. Though the informal industry contributes significantly still its contribution to the economy is neglected and the importance of informal sector is has not been given due regard from time-to-time. According to the report published by ILO India Labour Market Update (2016) and NSSO data (2011-12), it has been reported that more than $90 \%$ of the employment is generated from agricultural sector and approximately $70 \%$ from the non-agricultural sector falls under the informal category. The informal sector is dominant among all other sectors when it comes to employment creation. Though the informal sector is not contributing much to the national income still its dominance continues in India. The Ministry of Labour and 
Employment, GOI has categories the workforce from the unorganized sector into four broad categories based on the occupation, nature of job, especially distressed and service categories and the explanation to each category are as mentioned below:

a. Occupation: It includes small and marginal farmers, sharecroppers, fishermen, fisherwomen, beedi rollers, landless agricultural workers, animal husbandry workers, labelling and packing workers, leather workers, weavers; workers in brick-kilns and stone quarries, building and construction workers, artisans, salt workers, workers in saw mills and oil mills, etc.

b. Nature of Job: It includes attached agricultural labourers, migrant workers, bonded labourers, contract and casual labourers.

c. Especially Distressed Categories: It includes toddy tappers, scavengers, and head load carriers, drivers of animal-driven vehicles, loaders and un-loaders.

d. Service Categories: It includes domestic midwives. Workers, fishermen, barbers, newspaper vendors, vegetable and fruit vendors, etc, Along with these four categories, there is also a large population of unorganised labour workforce like cobblers, auto drivers, sericulture workers, handicraft artisans, hamals, power loom workers, handloom weavers, physically handicapped selfemployed persons, lady tailors, rickshaw pullers, carpenters, tannery workers and urban poor.

\section{Steps taken by GOI for upliftment of Informal Sector}

The GOI has taken several measures to ensure the upliftment of workers from Informal sectors and some of them are mentioned below:

a. Unorganized workers social security act, 2008

b. Indira Gandhi National Old Age Pension Scheme

c. National Family Benefit Scheme

d. Janani Suraksha Yojana

e. Handloom Weavers' Comprehensive Welfare Scheme (Mahatma Gandhi Bunkar Bima Yojana)

f. Aam Admi Bima Yojana

g. National Scheme for Welfare of Fishermen and Training and Extension

h. Rashtriya Swasthya Bima Yojana

i. Atal Pension Yojana

j. The Child Labour (Prohibition and Regulation) Amendment Act, 2016

k. National policy on skill development

1. National policy on HIV/AIDS

m. National Child labour policy

\section{Reasons for Growth in Informal Sectors:}

There are several reasons for growing informal sectors in India and some of them are mentioned below:

- Informal production processes in the manufacturing sectors.

- Migration by labour from rural areas to urban areas.

- Exponential population growth

- Less employment opportunities in the formal sector

- Programs and policies of Governments

- Poor literacy rate

- Rigid banking norms for poor labourers

- Lack of specialised skill training programmes

\section{Future Prospects:}

On daily basis, payments are being made in cash for the products and services which are essential for day-to-day life. These sectors have already seen a change and are on the verge of getting 
organized. In many big cities in India, several starts up are there who are working with the labours from unorganized sector in formal way. The unorganised sector in India which has high potential to be turn into organised sector:

1. House Rent - As per the data published by the income Tax department of India for the financial year 2014-15, it came to light that only 16 thousand house owners across India declared any sort of earnings from renting their premises excluding the commercial renting. Thus, it can be inferred that the house renting is having a high potential to get converted into a formal one.

2. Salary to Maid - There are several organization which are there in the market nationwide dealing with housekeeping services and things here are in formal way. Also there is a wave of digital payments in the country, which has made it much easier for both the parties to make the payment. Thus, it will definitely give boost to the formalization of industry.

3. Grocery Shopping - Already in India, organized retail sector is on boom and awareness among the customer and strict law has made it compulsory to provide bills of purchase. Approximately, 50-60\% shopkeepers have already started giving bills of purchase. But, it's a long way to covered when retailing will be $100 \%$ organized.

4. Agriculture-It is said that, Indian economy is an agrarian economy. Still a very little is being done for its betterment which is the biggest irony of the country. There is huge scope in this industry for its improvement. There is nothing in this sector which is formal or organized.
5. Transportation: communication is the back bone of any economy and in India, the owner of transport is given respect whereas the driver or handyman is the most neglected part of society. There is no formal structure regarding their earnings and work hour is not fixed. With the launch several online taxi services, the lives of most the driver has got improved similarly it is very much required to make this industry also formal.

\section{Conclusion:}

Unorganized sector is an important constituent of Indian economy still the most neglected sector. At this point of time an integrated approach is required to address the growing informal sector economy. It can only be achieved by education and skill development. It is also of high importance to motivate the workforce engaged in unorganized sector to be part of the organised sector and their contribution towards development of economy of the country. It has also become important to link the workforces from unorganized sector with the banks. The work force has to be educated in terms for credit facilities and other financial products and services. They should not be deprived of EPF, ELSI, Health and Accidental insurance etc. like the other workers in organized sectors are availing. Their work and contribution in economy should be recognized. At last but not the least there should be easy policy and procedure for the small, micro and agribusiness so that they could get encouraged to be a part of the legal framework of organized sector. Finally, steps have to be taken up by the government, considering all the hindrances and come up with a mutual solution for the upliftment of informal sector.

\section{References:}

1. (2012), "Report of the Committee on Unorganised Sector Statistics", National Statistics Commission, GoI

2. Amitabh Kundu (1999), "Urban Informal Sector in India: Macro trends and policy perspectives", ILO 
3. India Labour Market Update, ILO Country Office for India | July 2017. Retrieved on 20/02/2018 from http://www.ilo.org/wcmsp5/groups/public/---asia/--ro-bangkok/---sronew_delhi/documents/publication/wcms_568701.p df

4. A.Srija \& Shrinivas V. Shirke (2014), “ An analysis of the Informal Labour Market in India", CII

5. An analysis on the role of India's informal economy (Jul 14,2017) . Retrieved from The Hans India on 03/02/2018 from http://www.thehansindia.com/posts/index/YoungHans/2017-07-14/An-analysis-on-the-role-ofIndias-informal-economy/312388

6. Ajaya Kumar Naik (2009), "Measuring the informal economy in developing countries", IARIW

7. P. Mohanraj (2013), "Changing Scenario of Unorganised Sectors in India: An Empirical Study", Market Survey

8. https://en.wikipedia.org/wiki/Informal_sec tor; Retrieved on 20/02/2018

9. .http://nceuis.nic.in/ncemain.htm;

Retrieved on 20/02/2018

10. http://www.thehindu.com/opinion/column $\mathrm{s} /$ Chandrasekhar/indias-informal-

economy/article11119085.ece; retrieved on 03/03/2018

11. http://www.thehansindia.com/posts/index/ Young-Hans/2017-07-14/An-analysis-on-the-roleof-Indias-informal-economy/312388; retrieved on 03/03/2018

12. https://www.quora.com/Which-are-theunorganised-sectors-in-india-which-has-highpotential-to-turn-into-organised-sector; retrieved on $04 / 03 / 2018$

13. https://www.quora.com/What-is-thedifference-between-informal-and-formal-sectorsas-against-organised-and-unorganised-sectors; 04/03/2018

14. https://www.ibef.org/economy/indianeconomy-overview; retrieved on 05/03/2018

15. https://www.fundsforngos.org/developmen t-dictionary/specific-characteristics-of-the-formal- economy-and-informal-economy/; retrieved on $06 / 03 / 2018$

16. http://vikaspedia.in/socialwelfare/unorganised-sector-1/policies-forunorganised-sector; retrieved on 07/03/2018

17. https://www.bestcurrentaffairs.com/schem es-workers-unorganised-sector/; retrieved on 07/03/2018

18. https://www.india.gov.in/topics/labouremployment/unorganized-sector-workers; retrieved on $07 / 03 / 2018$

19. http://pib.nic.in/newsite/PrintRelease.aspx ?relid=163234; retrieved on 07/03/2018

20. http://pib.nic.in/newsite/mbErel.aspx?relid $=154133 ;$ retrieved on $07 / 03 / 2018$

21. http://www.dnaindia.com/india/reportgovernment-to-take-health-care-initiatives-fororganised-and-unorganised-workers-2007825; retrieved on $08 / 03 / 2018$

22. http://www.freepatentsonline.com/article/I ndian-Journal-Industrial-

Relations/235631658.html; retrieved on 08/03/2018

Index: GOI- government of India

ILO-international Labour organization EPF-Employee Provident Fund

ELSI-

NSSO-National Sample survey office 